\title{
NON-COERCIVE DEFENCE DIPLOMACY FOR CONFLICT PREVENTION
}

\author{
Robin M. Blake and Yolanda K. Spies ${ }^{199}$
}

\begin{abstract}
Since the end of the Cold War, the practice of defence diplomacy has received much attention, as has the proactive prevention of conflict. However, the preventive diplomacy of defence forces - something that is implied in the literature - has been less well articulated. This article addresses the theoretical lacuna by means of a pivotal qualification: the conceptual demarcation is narrowed down to non-coercive defence diplomacy (NCDD). NCDD is based on the principles of transparency, reputation and integrity and, per definition, it eschews violence or the threat thereof. It is therefore an exclusive subset of the wide range of international defence cooperation (generically referred to as 'defence diplomacy') in which defence forces engage. When NCDD activities are synchronised with the early stages of conflict development, the escalation of conflict is avoided. This is because NCDD requires of defence forces to conduct their cooperative international relations in a manner that promotes confidence and trust: essential elements of security that are integral to sustainable peace. Within the realm of diplomatic statecraft, the potential agency of defence forces in the prevention of conflict therefore warrants more strategic attention. It is especially required in Africa, where stable peace remains elusive and post-colonial military influence in intra- and inter-state politics has been mostly problematic.
\end{abstract}

\section{Keywords}

non-coercive, defence diplomacy, conflict prevention, confidence and security building measures, preventive diplomacy, Africa, peace.

\section{Introduction}

In the $21^{\text {st }}$ century, there is a global trend for government institutions to be more accountable and transparent to the publics they serve. Defence forces - whose agency is the primary focus of this article - are no different. A significant number of them are transforming to meet the exigencies of the changing international environment, and to achieve their raison d'etre better, namely to protect their states from violent conflict.

The resolution of conflict is an interdisciplinary concern in the humanities, and its management is a global imperative. This preoccupation reflects in both military and diplomatic instruments of foreign policy. The link has always been there: diplomats negotiating the beginning and ending of wars, and military commanders morphing into astute diplomats. It is not a new phenomenon for foreign policy actors to incorporate military elements into diplomatic processes, nor is it unheard of for defence forces to use diplomacy. As a result and across the world, the military-diplomacy relationship features prominently in policies and strategies of defence forces. 
In this regard, defence forces also practice 'preventive diplomacy'. The latter term was presaged in Article 99 of the United Nations (UN) Charter, but for the duration of the Cold War, the concept was not fleshed out, either in theory or in practice. Subsequently, new approaches in security studies emphasised human rather than state security and transcended the traditional conceptualisation of international security. Changes in the nature of war, notably the preponderance of intractable, intrastate conflicts with regional spill-over, made it necessary to avoid myopic, linear approaches to conflict resolution.

The more holistic and longer-term consideration of conflict management brought to the fore the necessity for proactive prevention of conflict. It was eloquently addressed in Egyptian statesman Boutros Boutros-Ghali's 1992 "Agenda for Peace", prepared at the start of his term as UN Secretary-General. Boutros-Ghali defined preventive diplomacy as "action to prevent disputes from arising between parties, to prevent existing disputes from escalating into conflicts and to limit the spread of the latter when they occur". 200

In the ensuing decades, preventive diplomacy received much attention, but the role of defence forces has been less well articulated. Indeed, the conceptual underpinnings of the defence-diplomacy conflict prevention nexus are under-researched and undertheorised. The utility of defence diplomacy is not in question; what is unclear is how (in a descriptive-analytical sense) and when (in an exploratory sense) defence diplomacy can contribute to conflict prevention. A more nuanced approach to defence diplomacy requires examination of the life cycle of conflict in order to extract conceptual markers for the timing and nature of proactive strategy, including the development of confidence-building measures (CBMs) prior to the onset of violent conflict.

The study on which article is based addressed the theoretical lacuna in the literature by means of a pivotal qualification. The conceptual demarcation was narrowed down to non-coercive defence diplomacy (NCDD). Excluded from the discussion will be conflict management processes, such as deterrence, threats and armed coercion, even if these are accepted measures used by defence forces to suppress, regulate and limit conflict. Very little substantive research on NCDD specifically is evident in the literature.

Our perspective is not exclusively Afro-centric, but it is influenced by the realities of our continent, which is beset by unresolved conflict. Post-colonial Africa has experienced significant militarisation of national politics and, as democratisation gains traction around the continent, it is essential that the dynamic presence and resources of defence forces be channelled into a positive new direction - that of conflict prevention. Conflict prevention has manifested in a few cases at domestic level, such as - 
- South Africa during its first democratic elections in 1994;

- $\quad$ Egypt during the Arab Spring of 2011;

- Zimbabwe during 2017 when Robert Mugabe was forced from power; and

- both Algeria and Sudan in 2019, during civil society challenges to autocratic presidencies.

There is however much potential for the diplomacy of defence forces to play a wider, inter-state role in the prevention of conflict.

The aim of our article is to explain the nexus between defence diplomacy and conflict prevention with a pertinent focus on NCDD. The article begins by explaining the context of defence diplomacy. We question the intuitive assumption that defence diplomacy is intrinsically non-coercive, and explicitly draw a distinction between coercive defence diplomacy and NCDD within a conflict prevention setting. This is followed by an analysis of conflict prevention, with reference to the conflict development model proposed by Christopher Mitchell. ${ }^{201}$ This is done in order to identify the link and relationship between NCDD activities - collectively operationalised as confidence- and security-building measures (CSBMs) - and how these potentially contribute to conflict prevention, together with an analytical framework. Our article concludes with three key findings concerning the utility and agency of NCDD in the prevention of conflict.

\section{Defence, as diplomacy}

In the contemporary era, diplomacy is undertaken by most government departments in support of shaping and implementing foreign policy. ${ }^{202}$ Defence ministries are a case in point, and their de facto diplomacy at international level has become known as 'defence diplomacy'. According to Gregory Winger, the term was first used by the British government during the 1990s, but it is not a recent practice. ${ }^{203}$ At bureaucratic-institutional level, the French introduced the attachment of military personnel to diplomatic missions in the Napoleonic period, during the early 1800 s. They did so in order to monitor military developments in their host countries, and the utility of the practice soon saw it emulated by other European countries. ${ }^{204}$ It took much longer, however, for the term 'defence diplomacy' to assume prominence in the international relations and military lexicon. This only happened during the 1990s, when defence forces across the world had to re-examine their roles in the nascent post-Cold War world order. The most obvious change was a shift away from a narrow focus on forging alliances against a common enemy to a wider mission of improving relations with former or potential enemies. ${ }^{205}$

Defence diplomacy found particular traction among member states of the North Atlantic Treaty Organisation (NATO) in response to the profound change in defence relations with former communist states in Eastern Europe. From their side, Warsaw Pact countries were also attempting to normalise defence relations with former adversaries. These changes, and defence forces' novel role in establishing relationships 
based on trust and mutual confidence, have not been limited to Europe. In Asia and Latin America (and Africa, but to a lesser extent), defence ministries have played key roles in promoting civil-military relations and implementing security sector reform in post-conflict states and states in democratic transition. Peacekeeping, peacebuilding and post-conflict reconstruction and development (PCRD) incorporate multilateral defence diplomacy as an adjunct to bilateral defence relations.

Multilateral defence relations have also become a hallmark of regional integration projects. Within the catchment area of the European Union (EU), the Southern Common Market (MERCOSUR) and other regional organisations, defence ministries have pooled military strategy and institutionalised the type of regular transgovernmental interaction that was previously the exclusive mandate of diplomats. Regional institutionalisation of defence diplomacy improves the management of regional relations more generally, and at a grassroots level, promotes the sharing of Humanitarian Assistance and Disaster Relief (HADR) efforts and Peace Support Operations (PSO).

Based on their assessment of the contribution of defence to Southeast Asia's regional security architecture, Tan and Singh cite the example of the Association of Southeast Asian Nations' (ASEAN) regional defence forums and institutions. ${ }^{206}$ These include the Five Power Defence Agreement (FPDA), ASEAN's Defence Ministers' Meeting (ADMM) and the ADMM-Plus. ${ }^{207}$ The various associations provide strategic depth to ASEAN's broader policies, afford constructive engagement among member states, and facilitate collective understanding of the strategic cultures that feed into the regional project.

In Africa, the regional integration of defence relations has been a Pan-Africanist ideal since Kwame Nkrumah advocated for an 'African High Command' in the late 1950s. Yet, at a practical level, this has not materialised. The Organisation of African Unity (OAU) was notoriously ineffectual in matters of conflict resolution, and its successor, the African Union (AU), has since its inception in 2002 struggled to capacitate the various components of its African Peace and Security Architecture (APSA). The most successful institutionalised defence cooperation on the continent occurs in West Africa, where the Economic Community of West African States (ECOWAS) has presided over several successful peace processes in the region. A recent example is its January 2017 intervention in The Gambia. Following decades of rapacious authoritarian rule, civilian anger erupted after incumbent President Jammeh refused to accept electoral defeat. With civil war seemingly imminent, ECOWAS launched 'Operation Restore Democracy', and promptly restored order in the country, after which the regional body oversaw (as it continues to do) a peaceful constitutional transition.

At global level, the proliferation in multilateral defence diplomacy has underlined the sheer scope and complexity of challenges to state security that have emerged over recent decades. In the process, defence ministries across the world have been compelled to widen and deepen their practice of defence diplomacy. However, the 
vagaries of the concept have become problematic. Winger cautions that it "not only lacks a meaningful definition, but has been contorted and stretched to the extent that it is now both descriptively vacuous and analytically hollow". ${ }^{208}$ The contemporary allure of defence diplomacy therefore risks its depiction as "an expedient catchall label". ${ }^{209}$

In order to ensure a balanced assessment of defence diplomacy, its generic meaning must be distilled by means of an additional typology. The essence of this typology is to question the intuitive assumption that defence diplomacy is intrinsically non-coercive, and therefore to draw an explicit distinction between coercive defence diplomacy and NCDD within a conflict prevention setting.

A coercive-non-coercive dichotomy is implied when the qualifying adjective is used in strategy documents. South African official policy documents, for instance, explicitly use the concept 'non-coercive defence diplomacy'. ${ }^{210}$ To this effect, in 2011, the Defence Secretariat Plan identified for the first time the use of military instruments non-coercively and as a "particular type of qualitative defence diplomacy". ${ }^{211}$ However, the policy documents do not explain why this qualification is necessary, how the two variations might differ, or what the link is to conflict prevention. The distinction therefore requires further clarification.

In a conventional sense, it could be argued that defence-as-diplomacy is intrinsically non-coercive and nothing else. The problem is that security literature abounds with references to 'coercive diplomacy', which conjures up the idea of a terminological extension into the realm of 'coercive defence diplomacy'. ${ }^{212}$ Coercive diplomacy involves the pursuit of diplomatic objectives through communication of threats, even the limited use of force. Even so, for many diplomatic scholars, the concept is problematic because it implies a unilateral and aggressive foreign policy. Coercive Diplomacy therefore deviates from the essentially pacific and reciprocal nature of diplomacy. This is why See Seng Tan prefaces his chapter on military diplomacy with the caution, "[m]ilitary diplomacy has often been described as an oxymoron. Militaries exist to wage wars or deter them by force whereas diplomacy involves the use of negotiation and dialogue to achieve national goals." ${ }^{13}$ In similar vein, Calvet de Magalhães insists on theorising diplomacy as opposed to any semblance of military force - the two options serving as extremes on a continuum of foreign policy instruments. ${ }^{214}$ For Calvet de Magalhães, as for many other scholars, coercive diplomacy is an incongruous construct, a contradiction in terms, which blurs conceptual parameters and professional mandates.

To add to the confusion, scholars differ (as do governments) in their conceptualisation of defence diplomacy. Often, the phrase 'military diplomacy' is used instead. Tan says that, while a distinction between defence and military diplomacy should be maintained, the lines are becoming so blurred that it is difficult to draw a clear boundary between the two. ${ }^{215}$ Indian scholar Raja Mohan makes a more attractive distinction, defining military diplomacy as "interaction and exchanges between the uniformed services". ${ }^{216}$ Defence diplomacy, on the other hand, is a broader and more 
inclusive concept. According to Mohan, it amounts to "activities undertaken by the entire defence establishment, including its civilian bureaucracy and the research and development establishments". ${ }^{217}$ As such, defence diplomacy refers to the practice whereby any member of a defence establishment who has official contact with a counterpart, defence institution or international organisation, establishes, broadens or deepens defence relations, including preventive diplomacy, in support of foreign policy objectives. Based on the aforesaid and for the purpose of this article, the overarching and broader concept - that of defence diplomacy - will be used.

In practice, defence diplomacy "runs the gamut from the significant to the mundane" as Jim Rolfe suggests. ${ }^{218}$ Included here are -

- bilateral and multilateral contacts between military and civilian officials;

- the appointment of defence attachés to serve in diplomatic missions (or their secondment to multilateral organisations);

- the conclusion of defence cooperation agreements;

- the training of defence and civilian personnel;

- $\quad$ the provision of expertise and advice on defence-related matters;

- the conduct of ship visits and other military-related exchanges;

- the staging of training exercises; and

- the provision of military equipment and technical expertise. ${ }^{219}$

Proponents of defence diplomacy, such as Cottey and Forster, suggest that it supports political commitments for cooperation, fosters common interests, promotes cooperation between defence forces, and demonstrates transparency to limit misunderstandings. ${ }^{220}$ We posit that the net result of these actions is conflict prevention, provided such actions are non-coercive and synchronised with conflict development, as we will discuss in due course.

As can be expected, there are detractors as well. Nick Bisley cautions that defence diplomacy has limitations in regions such as Asia, which are characterised by entrenched political cleavages. ${ }^{221}$

At domestic level, there are also many pitfalls that need to be avoided or managed with prudence. In her assessment of the 1998 United Kingdom (UK) Strategic Defence Review (SDR), Alice Hills identifies the flaws of defence diplomacy, in particular its linkages to Security Sector Reform (SSR). ${ }^{222}$ She emphasises that successful defence diplomacy must be integrated with programmes of other government departments and with other policy instruments for conflict resolution. If this is not done, defence diplomacy can be a source of friction between government departments over competition for scarce resources. ${ }^{223}$ Peter Leahy points out that defence diplomacy is time-consuming while not always yielding results, ${ }^{224}$ while Brendan Taylor cautions that its benefits are nebulous and difficult to quantify. ${ }^{225}$ At another angle, Hugh White 
dismisses the concept as little more than a public relations exercise by defence forces to reassure society of their security during times of peace. He rejects outright the notion that military officers might resolve complex international political problems, i.e. presume to practice diplomacy simply through "soldierly plain-speaking", 226

However, not all theorists hold such puritanical views of (defence as) diplomacy. Anton du Plessis argues that diplomacy is a vehicle for communicating and facilitating the full range of foreign policy actions: political, economic, cultural as well as military. ${ }^{227} \mathrm{He}$ explains that when diplomacy is used in a military context, its techniques could range from non-coercive to coercive in the situational context of both cooperation and conflict. The idea of 'smart power' - a strategic fusion of hard and soft power, as articulated by Joseph Nye - aligns with this more malleable interpretation of diplomacy. ${ }^{228}$

Nevertheless, coercive diplomacy is widely seen as a high-risk policy option that may have unintended consequences, and its utility in averting an escalation of conflict or achieving a de-escalation in existing levels of conflict, is limited.229 By extension, it can be deduced that 'defence as diplomacy' has restricted efficacy when it manifests as coercive defence diplomacy. The alternative, NCDD, therefore deserves special consideration in the context of conflict prevention.

\section{Conflict prevention}

According to Christopher Hill, conflict prevention is a "common thread which holds the (international) system together as it shows how interests and ideals can be yoked to each other". ${ }^{230}$ Surprisingly, though, interpretations of conflict prevention are fraught with contestation. A precise definition is required in order to assess its "promise and limitations", as Michael Lund observes, and to provide clarity for practical, coherent policy guidance. ${ }^{231}$

For the purpose of this article, conflict prevention is interpreted as 'the prevention of an escalation to violent (i.e. involving the use of military force) confrontation'. It therefore occupies a very specific position in the broader context of conflict management. The assumption is not that (all) conflict can be eliminated. After all, conflict is an inevitable and pervasive human phenomenon. The challenge, as Chadwick Alger notes, is to develop procedures for distinguishing between disruptive (violent) conflict and constructive conflict. ${ }^{232}$ The timing and location of related activities are critically important; hence, the need for an early warning capacity to identify which conflicts have the potential to become violent, or to determine whether a particular conflict is moving towards a violent phase. ${ }^{233}$

The imperative of decisions on timing and opportunity in the course of proactive conflict management - conflict prevention, specifically - necessitates a closer look at the life cycle of conflict. Various studies have been done on the structure of conflict, with different descriptions of its development stages. Among them is Lund's 'life history of a conflict' and the 'hourglass model' used by Ramsbotham, Woodhouse and 
Miall to contextualise what they describe as "conflict transformation, settlement and containment". ${ }^{234}$ We will, however, use Christopher Mitchell's 'conflict development model', in which he demarcates the progression of conflict through three distinct stages: incipient, latent and manifest conflict. ${ }^{235}$ This model is particularly useful as it provides a purposive framework that permits the synchronisation of the conflict stages with the associated NCDD activities.

A central theme in Mitchell's analysis (as indeed in conflict studies, generally) is that of goal incompatibility. Divergent values and resource scarcity could ultimately lead to conflict, and the earliest stage in this process - an inchoate phase that Ramsbotham et al. describe as "the emergence of differences" - is referred to by Mitchell as "incipient conflict". ${ }^{236}$ Without the benefit of hindsight, this stage could be difficult to diagnose, and even parties to the conflict might not recognise its existence. Consequently, incipient conflict is often ignored until there is escalation to a major catastrophe or widespread carnage. ${ }^{237}$

Incipient conflict escalates when the parties consciously recognise their goal incompatibilities and begin to consider alternatives. This stage, which Mitchell labels "latent conflict", does not necessarily have to be articulated or verbalised explicitly. ${ }^{238}$ However, it is characterised by tension and suspicion and polarisation between the parties. ${ }^{239}$ Sporadic violence might take place, and parties typically ensure deterrent military capabilities at this stage, because they perceive one another as enemies. ${ }^{240}$

The third stage in the life cycle of conflict is what Mitchell refers to as "manifest conflict". ${ }^{241}$ This occurs when a party takes identifiable action towards achieving its goals while simultaneously forcing the adversary to abandon or modify its behaviour. In this late stage of conflict, violence predominates and requires a different form of mitigation, namely conflict management. This involves limiting the spread of violence and bringing about a cessation in hostilities. ${ }^{242}$

For the purpose of this article, the first two stages of conflict, namely incipient and latent conflict, are the dominant albeit not the exclusive loci and foci of conflict prevention. The latitude for political and other options will decrease unless preventive action is taken, as Ramsbotham et al. maintain; hence, the positioning and alignment of conflict prevention with these development stages. ${ }^{243}$

Based on and aligned with his conflict development model, Mitchell postulates that pre-manifest remedial actions constitute conflict avoidance during incipient conflict, and conflict prevention during latent conflict. ${ }^{244}$ From his perspective, the latter is found when conflict attitudes and perceptions over recognised goal incompatibility are addressed. Although explicitly directed at latent conflict, conflict prevention by implication focuses on the goal incompatibility that underlies the conflict situation and is therefore linked to incipient conflict. On the one hand, international conflict avoidance has preventive implications to the extent that it inhibits the development of widely shared, over-arching or 'super-ordinate' goals. Such goals not only preclude narrow interests but also increase cooperation amongst adversaries by uniting them around a common purpose. ${ }^{245}$ On the other hand, the avoidance of malign goal 
incompatibility is an act that prevents conflict from progressing to a new level or even entering a next cycle. Furthermore, the processes of conflict prevention do not restrict conflict to an incipient threshold but also extend it into the domain of latent conflict.

At this point, it is important to note that incipient as well as latent conflict is part of what is now widely referred to as "negative peace". ${ }^{246}$ The more nuanced conceptualisation of peace was introduced by Johann Galtung who observed that peace could not be defined simply as the absence of violent conflict. ${ }^{247}$ Even without overt violence, so-called 'peace' might be unstable (negative); hence, the compelling idea that stable (positive) peace needs to be nurtured or 'built'. This imperative was emphasised in a June 2015 report by the UN High-Level Independent Panel on Peace Operations (HIPPO), which declares, "[p]eace processes do not end with a cease-fire, a peace-agreement or an election. Such events constitute merely a phase, rather than the conclusion, of a peace process. In fact, they may be times of great vulnerability". ${ }^{248}$ The reoccurrence of violent conflict after peace agreements in South Sudan, the Democratic Republic of the Congo, the Central African Republic, Côte d'Ivoire and Mozambique are just a few of the many examples of negative peace that has prevailed in Africa.

The implication is that conflict does not necessarily develop in a linear manner. It could move through (potentially self-perpetuating) cyclical patterns, become dormant, diffuse into secondary proxy wars, or link into other conflicts. Conflict behaviour, a complex interplay of action and reaction, has a tendency to become increasingly harmful and coercive when parties 'mirror-image' each other's actions. A related consideration is that conflict - despite its proclivity to escalate - does not always develop sequentially through all the identified stages. It could remain suppressed during the incipient or latent stages, and as Mitchell points out, manifest conflict might even be inhibited indefinitely as a result of an adversary's overwhelming coercive power. ${ }^{249}$ Here the warning of Hill that preventing conflict during the incipient stage could suppress rather than resolve conflict should be kept in mind. ${ }^{250}$ On the other hand, restricting conflict to a pre-manifest stage could prevent its degeneration into a vortex of recurring violence. The development of conflict is affected by the emergence of new issues and involvement of new stakeholders, and these dynamics add to the complexity of conflict resolution. Moreover, conflict formations are interlinked, as Ramsbotham et al. point out. ${ }^{251}$ The 'communicable' nature of conflict means that local and regional conflicts almost invariably acquire an international profile, unless they are resolved timeously and comprehensively.

The non-linear nature of conflict development, and the fact that any stage of conflict could serve as roots for another conflict, explain why conflict prevention is part of post-conflict strategies as well. As Boutros-Ghali put it in his seminal Agenda for Peace, "the concept of peace-building as the construction of a new environment should be viewed as the counterpart of preventive diplomacy ... preventive diplomacy is to avoid a crisis; post-conflict peace-building is to prevent a recurrence". ${ }^{252}$ Incipient conflict can therefore reoccur after the 'end' of manifest conflict and in the wake of ostensible peace deals, if the peace that has been achieved, is negative. 
Boutros-Ghali made it clear that any reduction in the likelihood of conflict between states requires the creation of trust. This necessitates deliberate confidence building in situations where there is no shared understanding of the conflict. Prevention of conflict is based on identification of the causes of tension and suspicion, and implementation of appropriate responses to promote mutual interests. ${ }^{253}$ Positive incentives are of critical importance in preventive diplomacy, as Peter Jakobsen and Alexander George contend, and this implies the use of confidence-building measures to establish trust and certainty between parties to the conflict. ${ }^{254}$ This prevents intraor interstate disputes from escalating into violence, and when escalation does occur, CBMs could limit the extent of violence. ${ }^{255}$

CBMs are specifically designed to modify behaviour. They are based on transparency and involve verifiable activities that establish predictable behaviour to prevent, manage and resolve crises that have the potential to escalate into violence. ${ }^{256}$ The Organization for Security and Co-operation (OSCE) in Europe, for example, makes extensive use of CBMs. ${ }^{257}$ The purpose is to avoid uncertainties among states, which might cause an intentional or unintentional escalation of hostilities. Related activities could be formal and informal; unilateral, bilateral and multilateral; military and political; and could be state-to-state as well as non-governmental activities. ${ }^{258}$

Siân Herbert distinguishes between two types of CBMs that prevent conflict escalation: military/security versus humanitarian, social and cultural. ${ }^{259}$ Both types, in line with the OSCE viewpoint, can be used in all phases of a conflict cycle. ${ }^{260}$ Stefan Wolff cautions however that the use of CBMs is dependent on and therefore varies in accordance with the time frame. ${ }^{261}$ In the short term, they are designed to prevent conflict escalating into violence; in the medium term, they promote trust through increased contact; and in the long term, they pave the way for meaningful and sustainable conflict settlement.

Several decades of theory building on conflict resolution have underlined, without contestation, the critical importance of prevention. Yet, as the HIPPO report points out, it "has not been sufficiently invested in", even though "[t]he prevention of armed conflict is perhaps the greatest responsibility of the international community". ${ }^{262}$ This is a deficiency in international organisations, as it is in individual states' defence diplomacy. It is to the latter that we will now turn.

\section{Preventive defence diplomacy}

Defence diplomacy and conflict prevention interact against the backdrop of what Ronald Barston describes as "a complex and evolving" relationship between diplomacy and security. ${ }^{263}$ The utility value of defence diplomacy is that it forestalls countries from becoming adversarial. It does so by reducing tension, preventing issue escalation and facilitating information flow, which enhance mutual understanding of interests and capabilities. ${ }^{264}$ As discussed earlier, the idea of defence diplomacy implies both coercive and non-coercive activities. The coercive element can be detected in literature on preventive diplomacy also. Boutros-Ghali, for instance, 
noted that preventive diplomacy requires CBMs as well as early warning ("based on information gathering and informal or formal fact-finding"), and added, "it may also involve preventive deployment and, in some situations, demilitarized zones". ${ }^{265}$ Lund builds on Boutros-Ghali's thesis and widens the discussion on the recourse of preventive diplomacy to military options. ${ }^{266} \mathrm{He}$ divides these military approaches and tools into two groups, namely "[r] estraints on the use of armed force" and "[t]hreat or use of armed force". As part of the second category, he lists:

- deterrence policies and security guarantees;

- $\quad$ maintaining or restoring local or regional balances of power; and

- the use or threat of limited force.

It is clear that these options are essentially coercive, and therefore of limited utility for our analytical framework.

Lund's first category, "[r]estraints on the use of armed force", likewise includes some examples of defence actions that could be deemed coercive: the pre-emptive use of peacekeeping forces to deter and contain; demilitarised zones, safe havens and peace zones; as well as arms embargoes and blockades. On the other hand, he also includes options that are evidently non-coercive:

- $\quad$ arms control regimes (including monitoring);

- $\mathrm{CBMs}$;

- $\quad$ non-aggression agreements;

- $\quad$ non-offensive force postures; and

- military-to-military cooperation.

Conducting defence diplomacy to prevent conflict from becoming violent requires the associated activities to take place "in vulnerable places and times", i.e. during times of unstable peace. ${ }^{267}$ This implies that it should happen during the early (incipient and latent) stages of conflict. As soon as differences emerge, it is fitting to initiate activities, such as the establishment of military-to-military cooperation, to eliminate or mitigate differences.

Considering the aims of defence diplomacy and to ensure that incipient conflict does not escalate into latent conflict (or that latent conflict does not escalate into manifest conflict), defence diplomacy activities must be synchronised with conflict development stages. Crucially, these activities must exhibit behaviour that -

- $\quad$ serves common interests;

- $\quad$ supports mutual political commitments;

- $\quad$ promotes cooperation in the defence environment; and

- $\quad$ assists in modifying conflictual behaviour. 
Key to this process is the mutual building of confidence. Activities must be geared towards eliminating differences and contradictions before polarisation occurs to address goal incompatibility and to encourage constructive behaviour and dialogue. ${ }^{268}$

When diplomacy is used in the context of CBMs to prevent conflict, it focuses on similarities rather than on differences, and in this way, misunderstandings are clarified and uncertainties are reduced. Against the backdrop of defence cooperation, when CBMs involve security-related activities, which build confidence, they are referred to as confidence- and security-building measures (CSBMs). CSBMs continue to be used with varying degrees of success to defuse tension and reduce the potential for violent conflict. Their use has been instrumental in reducing the potential for conflict between nuclear power rivals India and Pakistan, inter alia over Kashmir and the Siachen Glacier; and to reduce tension and prevent an 'accidental' escalation in the use of force between the People's Republic of China (PRC) and its nemesis, Taiwan. ${ }^{269}$

Most defence forces undertake activities to promote defence cooperation with selected partner states. Since these activities fall outside the realm of warfare and combat operations, and mainly take place during periods of relative peace and stability, they can be construed and operationalised collectively as CSBMs. Included are:

- entering into formal agreements;

- conducting joint combat simulation exercises;

- providing training;

- high-level, working and ship visits;

- holding seminars;

- intelligence exchanges and early warning information dissemination;

- establishing common doctrine and procedures;

- deploying defence attachés;

- procuring or supplying armaments and technology;

- providing HADR;

- $\quad$ sports and cultural exchanges; and

- even prisoner exchanges.

Similarly, the OSCE also operationalises the following categories of what it terms 'CSBMs':

- annual exchange of information;

- defence planning;

- risk reduction; 
- military contacts;

- prior notification of certain military activities;

- observation of military activities, such as land, air and naval exercises when the force level exceeds 13000 troops;

- the exchange of annual calendars of military activities;

- constraining provisions, such as placing a limit on the number and sizes of exercises by countries;

- measures to ensure compliance with and verification of the provisions;

- regional measures for security cooperation, such as agreements that promote transparency; and

- reducing the risk of military conflict. ${ }^{270}$

In this respect, Lund concurs that CBMs are among a number of military tools to prevent conflict. ${ }^{271}$ Similarly, Ackermann is of the opinion that CBMs have specific utility in what she terms "operational or structural prevention". ${ }^{272}$

Not all commentators consider confidence building to be part of defence diplomacy. For instance, Cottey and Forster state, "[a]rms control, non-proliferation and confidence building do not fit within the definition of defence diplomacy." 273 In contrast, the Indonesian Ministry of Defence identifies CBMs as central to their conceptualisation of defence diplomacy, particularly for bilateral and multilateral engagement. ${ }^{274}$ This validates the notion that defence diplomacy can be utilised for building confidence. ${ }^{275}$ When used non-coercively, defence diplomacy not only builds confidence but also contributes to conflict prevention.

At policy formulation level, several states have ventured into the defence diplomacy-conflict prevention nexus. Justin Fris recounts how, in 1993, the Australian Minister of Defence linked the need to engage regional nations, maintain relations with alliances, and confirm a commitment to international peace and security to Australian defence. ${ }^{276}$ In 1994, the German Ministry of Defence went a step further and recognised that 'military-political' cooperation with former Warsaw Pact countries was a core mission to detect and resolve conflict before it escalated to military confrontation. ${ }^{277}$ Defence diplomacy similarly featured as a core mission in the UK's 1994 SDR in which it was defined as the provision of "forces to meet the varied activities undertaken by the Ministry of Defence to dispel hostility, build and maintain trust and assist in the development of democratically accountable armed forces, thereby making a significant contribution to conflict prevention and resolution". ${ }^{278}$

Canada followed the example of the United Kingdom by adopting defence diplomacy as official policy in 2005, describing it as a defence tool for shaping the international environment to contribute to stability by building relations. ${ }^{279}$ In the 2012 Spanish defence diplomacy plan, defence diplomacy is described as - 
The various international activities based mainly on dialogue and cooperation, carried out bilaterally by the Ministry of Defence with our allies, partners and other friendly countries to promote the accomplishment of defence policy objectives in support of Spanish foreign policy. ${ }^{280}$

These international activities comprise security sector reform, reinforcing security and defence capabilities, and - notably - conflict prevention. Whereas Canada and Australia are ambivalent about the nexus, the United Kingdom and Spain specifically link defence diplomacy to conflict prevention. The comprehensive description thereof by Germany, as earlier mentioned, emphasises the importance of detecting and resolving conflict before it escalates and places former enemies foremost in the integrated military-political context.

Nevertheless, Sidney Bearman warns that it is "naïve" or "misleading" to suggest that conflict could be prevented by military-to-military contacts built through defence diplomacy, as today's friend may be tomorrow's foe. ${ }^{281}$ Bilateral and multilateral defence diplomacy and related activities can be used for preventing conflict but not in isolation from the political and foreign policy objectives of a government. To be sure, defence diplomacy is not an all-encompassing panacea for preventing conflict, as its utility is restricted to defence-related areas. While defence diplomacy has a general connotation, its utility in conflict prevention must be conceptually elucidated.

\section{An analytical framework for non-coercive defence diplomacy as conflict prevention}

A few authors have explicitly linked defence diplomacy and conflict prevention. Rolfe is of the opinion that, because defence diplomacy develops trust and enhances constructive relationships, it also contributes to conflict prevention and resolution. ${ }^{282}$ Based on a wider conceptualisation, Du Plessis provides a framework that contextualises the use of defence diplomacy as part of peace strategies and conflict prevention. ${ }^{283}$ Hence, Rolfe and Du Plessis agree that defence diplomacy is used for conflict prevention, to the extent that it is non-belligerent, pacific-persuasive, grounded in trust, based on common interests and constructive relationships, transparent, and inclined to defence reform and cooperation. Some facets of this nexus, however, must be articulated emphatically to indicate how and when defence diplomacy contributes to peace and prevents cycles of violent conflict.

Defence diplomacy for preventing conflict manifests at various levels and in a number of ways. The utility of these levels and ways lies in allaying fears and suspicions of former or potential enemies that have their origins in historical perceptions, political differences or tangible disputes, such as territory or maritime zones. ${ }^{284}$ This means that defence diplomacy, in a bilateral or multilateral mode, must be coordinated and employed at strategic, operational and tactical level when dealing with and preventing conflict. The suggested framework (see Table 1) has preventive diplomacy as its primary point of departure. Accordingly, defence diplomacy is 
positioned as a means (i.e. a particular type of diplomacy) within the process of preventive diplomacy. In addition, the emphasis is specifically on NCDD during periods of pre-manifest (incipient and latent) conflict, although with the inclusion of a qualified preventive role in respect of manifest conflict.

In this respect, NCDD establishes, nurtures and expands defence ties to change conflict situations, attitudes or behaviour to engender trust and confidence, and it relies on the will of the parties to acknowledge and resolve differences associated with pre-manifest conflict. Nevertheless, NCDD is not without preconditions. First, emotional orientation towards partners and allies must be trusting, pacific, credible, collaborative and transparent. Second, discordant goals are inevitable in international relations implying that NCDD using confidence-building to modify behaviour must be ongoing. In essence, NCDD calls for pragmatism rather than idealism. NCDD cannot be used in all circumstances - it is not a blanket solution, it does not replace coercive defence diplomacy, and it is unlikely to be effective when there are deep and entrenched political differences between states.

As an over-arching concept, NCDD can therefore play a role by altering conflict perceptions, reducing aggression and resentment while the deliberate use of CSBMs could reduce mistrust and suspicion. In the context of defence diplomacy responses and activities, CSBMs are classified into five sequential categories, namely bilateral and multilateral dialogue; the conclusion of agreements; information exchange; establishing defence ties at diplomatic level; and providing tangible substance to undertakings by participating in defence cooperation programmes. It is nonetheless of crucial importance that activities in support of NCDD be synchronised to prevent disputes from arising before conflict intensifies and becomes violent. This means that specific activities are used at specific times and at specific levels for specific purposes, as represented in Table 1 as a concept-based framework for linking NCDD and conflict prevention.

NCDD has its primary utility during incipient and latent conflict; hence, the need for a uniquely designed early warning system that focuses on the indicators of both. NCDD therefore adopts two approaches that follow in sequence to mitigate incipient and latent conflict. The first is conflict avoidance, which is intended to keep levels incipient; and the second is conflict prevention, which is intended to keep levels latent (or to reduce it to the incipient level).

Conflict avoidance during the incipient stage primarily focuses on establishing defence ties, starting at the highest level and deepening the ties to functional levels. The purpose is to build relationships both formally and informally in bilateral and multilateral environments. Horizontal networks are established as a foundation, where possible drawing on historical commonalities. (France does this masterfully, as is evident from its extensive defence-related influence in the African Francophonie.) Hegemony and domination are deliberately avoided as these are at odds with noncoercion, which emphasises building trust and credibility. A particular activity during this stage is joint NCDD research and training, especially in a regional context, as 
this maximises the use of scarce resources and also fosters common approaches to avoiding conflict and embedding shared values.

Relations are deepened for preventing conflict during the latent stage, specifically using CSBMs to modify behaviour by orientating defence forces towards collaboration and cooperation. In this way, meaning and substance are given to the relationships established during the incipient stage.

\begin{tabular}{|c|c|c|}
\hline $\begin{array}{l}\text { CONTEXT } \\
\text { Pre-manifest } \\
\text { conflict stages }\end{array}$ & \multicolumn{2}{|c|}{$\begin{array}{l}\text { Incipient conflict: conflict is largely subliminal and the parties might even be unaware of its imminence. However, there are } \\
\text { vestiges of goal incompatibility. } \\
\text { Latent conflict: parties acknowledge the existence of mutually incompatible goals and begin considering alternatives. }\end{array}$} \\
\hline & \multicolumn{2}{|c|}{$\begin{array}{l}\text { Discordant goals are inevitable in international relations implying that NCDD using confidence building to modify behaviour is } \\
\text { ongoing. Activities must support political objectives, must not incite or stimulate incompatibility, must focus on congruency, and } \\
\text { must ensure that behaviour remains within mutually agreed boundaries, which preclude violence. }\end{array}$} \\
\hline & \multicolumn{2}{|c|}{ Non-coercive defence diplomacy conflict approaches } \\
\hline & \multicolumn{2}{|r|}{ Pre-manifest conflict stages } \\
\hline & The incipient conflict stage & The incipient conflict stage \\
\hline & Conflict avoidance & Conflict prevention \\
\hline $\begin{array}{l}\text { Bilateral and } \\
\text { multilateral } \\
\text { strategies to } \\
\text { prevent the } \\
\text { escalation of } \\
\text { conflict }\end{array}$ & $\begin{array}{l}\text { Relations are established with the defence } \\
\text { forces of partner countries and organisations } \\
\text { to prevent an escalation from incipient to } \\
\text { latent conflict. Related NCDD activities } \\
\text { are aimed at: } \\
\text { - identifying goal incompatibility or } \\
\text { emerging differences; } \\
\text { - identifying and pursuing complementary } \\
\text { goals; } \\
\text { - establishing common values and } \\
\text { interests; } \\
\text { - pursuing broader objectives of } \\
\text { cooperation and trust; } \\
\text { - supporting mutual political } \\
\text { commitments; } \\
\text { - ensuring expectations regarding } \\
\text { cooperation are kept within reasonable } \\
\text { limits; } \\
\text { - promoting transparency by revealing } \\
\text { intent and capability; } \\
\text { - allaying aggression, mistrust and } \\
\text { suspicion; } \\
\text { - changing perceptions concerning } \\
\text { defence activities that may be construed } \\
\text { as belligerent; } \\
\text { - using prevention to keep incipient } \\
\text { conflict within acceptable levels } \\
\text { according to agreed parameters; and } \\
\text { - eschewing coercion as an alternative to } \\
\text { prevent a maligned conflict spiral. } \\
\text { In support of the above, it is essential } \\
\text { during this (incipient) stage to establish a } \\
\text { foundation for NCDD that concentrates } \\
\text { on defence diplomacy research and } \\
\text { multilaterally to develop common doctrine } \\
\text { regarding NCDD for conflict prevention. } \\
\text { by facilitating revolving-door exchanges } \\
\text { institutions or think tanks that specialise in } \\
\text { defence diplomacy and conflict prevention }\end{array}$ & 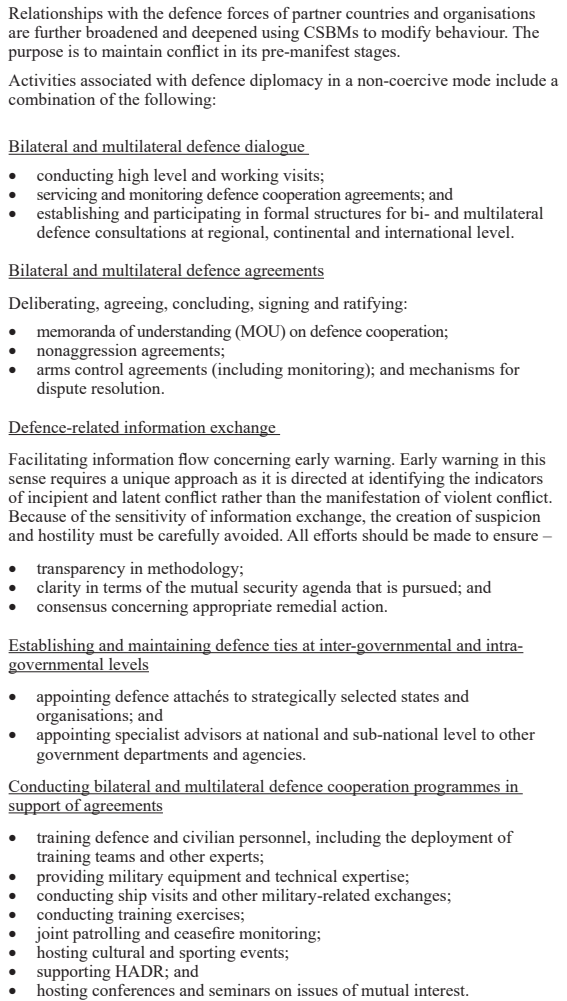 \\
\hline
\end{tabular}




\section{Conclusion}

The study on which this article is based set out to explore, in the first instance, the idea of defence as diplomacy. The practice of de facto diplomacy by armed forces is gaining traction worldwide, and is fuelled by democratisation of intrastate as well as interstate politics. It is important to keep in mind, however, that within the hierarchy of foreign policy, the international relations of defence forces remain a subset of broader diplomatic statecraft. Diplomacy can be shored up with military threat (amounting to coercive diplomacy) but that particular diplomatic-military nexus is not the equivalent of defence forces employing diplomatic tools. In both instances, defence forces implement (rather than formulate) foreign policy. For the purpose of our research, we were particularly interested in the agency of defence forces, when the diplomatic goal is conflict prevention.

Three findings resulted from our theoretical contextualisation. The first is that the conceptual variables - defence diplomacy, conflict and its prevention, even the very notion of peace - are contested, and present a problem of definition. For descriptiveanalytical purposes, it was therefore necessary to settle on stipulative meanings and accounts. The second finding is that the defence diplomacy-conflict prevention nexus is seldom theorised as such, despite evidence in the literature of implicit links when one or the other is theorised. The third - and related to the second - is that defence diplomacy is not specifically theorised from a non-coercive perspective. Considering its assumed utility for preventing conflict, NCDD therefore required further clarification.

NCDD is based on the principles of transparency, reputation and integrity, and non-violent methods. It entails convincing, persuading, negotiating or behaving in a manner that serves common interests and values, it supports mutual political commitments and it promotes defence cooperation. As such, it focuses on former or potential adversaries (rather than on current opponents in an adversarial relationship) as well as on existing or potential allies and partners. NCDD is an alternative to the use of force and thus essentially different from coercive defence diplomacy. It establishes, nurtures and expands defence ties to change situations, attitudes and behaviour, and it engenders trust and confidence. These attributes bestow on NCDD distinct agency in conflict prevention.

Conflict prevention denotes an element of timing, and therefore NCDD and its associated activities, specifically CSBMs, must be synchronised with the first two stages of conflict development, namely incipient and latent conflict. Ostensible peace can be negative (the continent of Africa is rife with examples!) and this means that NCDD is essential to safeguard incipient conflict from escalating into latent conflict, and inhibiting latent conflict from escalating into a manifest form. A conflict 'climate change' is thus effected through the elimination of differences and contradictions before polarisation occurs, or if polarisation has already taken place, through changing conflict attitudes, perceptions and behaviour, In summary, it can be deduced that when NCDD is used proactively during incipient or latent stages of conflict, it plays a role in promoting positive peace. 
The scope and space available in this article did not allow for an in-depth study of the theoretical framework, and it is recommended that more research be done to determine the parameters and indicators of NCDD. The differences between and overlap of non-coercive and coercive defence diplomacy, the transition of the one to the other, and the implications of this transition should be examined, inter alia. Case study application is also essential. The topic has global application because, as a policy instrument, NCDD is accessible to all states, regardless of their relative power. This bestows on NCDD much potential as a tool of soft power. Middle powers, such as Canada, Sweden and South Africa, have carefully nurtured their soft power profile, and indeed their international identity, based on a conflict resolution track record.

From our own vantage point, the role of defence forces in Africa deserves special attention. These forces have been politically prominent (and often maligned) in the post-colonial dispensation, but their potential to prevent conflict is a largely untapped resource. The crafting of NCDD policy frameworks and investment in training to allow for its implementation are therefore essential. At a normative level, NCDD also resonates with the historically important integration agenda of the continent and its various sub-regions. This begs a much more vigorous research agenda than the current study.

\section{Endnotes}

${ }^{199} \mathrm{Col}$ (ret) Robin M Blake is a part-time lecturer in the Department of Political Sciences at the University of Pretoria. This article is based on his Master of Security Studies dissertation, completed in 2016 at the University of Pretoria. Dr Yolanda K Spies is a senior research fellow at the Chair in African Diplomacy and Foreign Policy, University of Johannesburg.

${ }^{200}$ B Boutros-Ghali. An agenda for peace: Preventive diplomacy, peacemaking and peace-keeping. Report of the Secretary-General, United Nations GA and SC. A/47/277, S/24111. 17 June 1992, Par. 20.

${ }^{201}$ Mitchell, C.R. The Structure of International Conflict. Houndsmills: MacMillan. 1989: 49-51.

${ }^{202}$ RP Barston. Modern diplomacy. Second ed. Harlow: Addison Wesley Longman, 1997, 1.

${ }^{203}$ G Winger. "The velvet gauntlet: A theory of defence diplomacy". Institut für die Wissenschaften vom Menschen. 2014. < $<$ ttp://www.iwm.at/publications/5junior-visiting-fellows-conferences/vol-xxxiii/the-velvet-gauntlet/> Accessed on 21 March 2018.

${ }^{204} \mathrm{KM}$ Marisa. "Consolidated military attaché and security assistance activities: A case for unity of command". Defence Intelligence Journal 12/2. 2003. 66.

${ }^{205}$ S Blank. "Defence diplomacy, Chinese style". Asia Times Online. 2003. <http:// www.atimes.com/atimes/China/EK11Ad02.html $>$ Accessed on 13 December 2015; A Cottey \& A Forster. Reshaping defence diplomacy: New roles for military assistance and cooperation. Adelphi paper no. 365. Oxford: Oxford University Press, 2004, 69. 
${ }^{206}$ SS Tan \& B Singh. "Introduction”. Asian Security 8/3. 2012. 228.

${ }^{207}$ The ADMM-Plus countries include ten ASEAN Member States, namely, Brunei Darussalam, Cambodia, Indonesia, Lao PDR, Malaysia, Myanmar, the Philippines, Singapore, Thailand and Viet Nam, and eight Plus countries, namely Australia, China, India, Japan, New Zealand, ROK, Russian Federation, and the United States. https://admm.asean.org/index.php/aboutadmm/about-admm-plus.html. Accessed on 31 May 2019.

${ }^{208}$ Winger op. cit., p. 2.

${ }^{209}$ Tan \& Singh op. cit., p. 226.

${ }^{210}$ Republic of South Africa, Department of Defence. Defence Secretariat strategic plan for the fiscal years 2011/12-2015/16. Pretoria, 2011, 35.

${ }^{211}$ Ibid., pp. 35-36.

${ }^{212}$ See, among others, SG Fetic. "Fields of classic diplomacy with which defence diplomacy interacts horizontally: Preventive diplomacy, coercive diplomacy". Revista Academiei Fortelor Terestre 1/73. 2014. 10-15; AL George. "Strategies for preventive diplomacy and conflict resolution: Scholarship for policymaking". PS: Political Science and Politics 33/1. 2000. 15-19; PV Jakobsen. "Coercive diplomacy". In A Collins (ed.), Contemporary security studies. Third ed. Oxford: Oxford University Press, 2013.

${ }^{213}$ SS Tan. "Military diplomacy". In C Constantinou, P Kerr \& P Sharp (eds), The Sage handbook of diplomacy. London: Sage, 2016, 591.

${ }^{214} \mathrm{~J}$ Calvet de Magalhães. The pure concept of diplomacy. Transl. BF Pereira. New York, NY: Greenwood, 1988, 8-13.

${ }^{215}$ Tan op. cit., p. 592.

${ }^{216}$ CR Mohan. "From isolation to partnership: The evolution of India's military diplomacy”. Institute for Defence Studies and Analyses. 2012. $<$ http://idsa. in/system/files/jds 51 kamuthanna.pdf $>$ Accessed on 10 December 2015.

${ }^{217}$ Ibid., p. 2.

${ }^{218} \mathrm{~J}$ Rolfe. Regional defence diplomacy: What is it and what are its limits? Wellington: Centre for Strategic Studies, 2015, 2.

${ }^{219}$ Cottey \& Forster op. cit., p. 7; Tan op. cit., pp. 594-596.

${ }^{220}$ Cottey \& Forster op. cit., p. 27.

${ }^{221} \mathrm{~N}$ Bisley. The possibilities and limits of defence diplomacy in Asia. Centre of Gravity Series paper no. 17. Australian National University, 2014, 14. $\quad$ http://sdsc.bellschool.anu.edu.au/sites/default/files/publications/ attachments/2016-03/cog 17 web.pdf Accessed on 9 December 2015.

${ }^{222}$ A Hills. "Defence diplomacy and security sector reform". Contemporary Security Policy 21/1. 2000. 47-49.

${ }^{223}$ S Bearman. "New challenges to defence diplomacy". Strategic Survey 100/1. 1999. 38-53; Hills op. cit., p. 51. 
${ }^{224} \mathrm{P}$ Leahy. Military diplomacy. Centre of Gravity Series paper no. 17. Australian National University, 2014, 16. http://sdsc.bellschool.anu.edu.au/sites/ default/files/publications/attachments/2016-03/cog_17_web.pdf Accessed on 9 December 2015.

${ }^{225}$ B Taylor. Australia's defence diplomacy: Time for a stocktake. Centre of Gravity Series paper no. 17. Australian National University, 2014, 5. http://sdsc. bellschool.anu.edu.au/sites/default/files/publications/attachments/2016-03/ cog 17 web.pdf Accessed on 9 December 2015.

${ }^{226} \mathrm{H}$ White. Grand expectations, little promise. Centre of Gravity Series paper no. 17. Australian National University, 2014, 10-11. http://sdsc.bellschool.anu. edu.au/sites/default/files/publications/attachments/2016-03/cog_17_web. pdf Accessed on 9 December 2015.

${ }^{227}$ A du Plessis. "Defence diplomacy: Conceptual and practical dimensions with specific reference to South Africa". Strategic Review for Southern Africa 30/2. 2008. 89-90.

${ }^{228}$ JS Nye. "Get smart: Combining hard and soft power". Foreign Affairs. July/August 2009. < http://www.foreignaffairs.com/articles/65163/joseph-s-nye-jr/getsmart $>$ Accessed on 13 August 2014.

${ }^{229}$ George op. cit.; Jakobsen op. cit.

${ }^{230} \mathrm{C}$ Hill. "The EU's capacity for conflict prevention". European Foreign Affairs Review 6. 2001. 315.

${ }^{231}$ MS Lund. Preventing violent conflicts: A strategy for preventive diplomacy. Washington, DC: United States Institute of Peace, 1997, 32.

${ }^{232}$ CF Alger. "Peace studies as a transdisciplinary project". In C Webel \& C Galtung (eds), Handbook of peace and conflict studies. Abingdon: Routledge, 2009, 312.

${ }^{233}$ George op. cit., p. 6; Lund op. cit., p. 37; O Ramsbotham, T Woodhouse \& T Miall. Contemporary conflict resolution: The prevention, management and transformation of deadly conflicts. Third ed. Cambridge: Polity Press, 2011, 132-133.

${ }^{234}$ Lund op. cit., p. 38; Ramsbotham et al., op. cit., p. 14.

${ }^{235}$ Mitchell, op. cit.,

${ }^{236}$ Ramsbotham et al., op. cit., p. 13; Mitchell op. cit., p. 50.

${ }^{237}$ George op. cit., p. 15.

${ }^{238}$ Mitchell op. cit., p. 50.

${ }^{239}$ Ramsbotham et al., op. cit., p. 13.

${ }^{240}$ Lund op. cit., p. 39.

${ }^{241}$ Mitchell op. cit., pp. 50-51.

242 P Wallensteen. Understanding conflict resolution. Third ed. London: Sage, 2012, 53.

${ }^{243}$ Ramsbotham et al. op. cit., pp. 123-124.

${ }^{244}$ Mitchell op. cit., pp. 256-257. 
${ }^{245}$ Ibid., pp. 261-262.

${ }^{246} \mathrm{~J}$ Galtung. Peace by peaceful means: Peace and conflict, development and civilisation. London: Sage, 1996, 265.

${ }^{247}$ Ibid.

${ }^{248}$ UN (United Nations). Uniting our strengths for peace: Politics, partnership and people. Report of the High-Level Independent Panel on Peace Operations (HIPPO). 16 June 2015. 34.

${ }^{249}$ Mitchell op. cit., p. 51.

${ }^{250}$ Hill op. cit., p. 324.

${ }^{251}$ Ramsbotham et al. op. cit., pp. 127 \& 129.

${ }^{252}$ Boutros-Ghali op. cit., par. 57.

${ }^{253} \mathrm{~S}$ Herbert. Lessons from confidence building measures. Governance Social

Development Humanitarian Conflict Helpdesk research report no. 1131. Birmingham: University of Birmingham, 2014, 4.

${ }^{254}$ Jakobsen op. cit., p. 254; George op. cit., p. 16.

${ }^{255}$ Lund op. cit., p. 39. See also L Nathan. Where does mediation fit in? Briefing note on definitions and categories of UN peace interventions. Pretoria: UN High Level Mediation Course, 2013.

${ }^{256} \mathrm{~S}$ Wolff. "International Peace Institute Expert Workshop on Confidence-building Measures: An Overview of Elite-level Options". 2011. <http://stefanwolff. com/talks/expert-workshop-on-confidence-building-measures/ $>$ Accessed on 8 April 2018.

${ }^{257}$ OSCE (Organization for Security and Co-operation in Europe). OSCE guide on non-military confidence-building measures (CBMs). Compiled by the Secretariat's Conflict Prevention Centre. Vienna: OSCE, 2012, 11.

${ }^{258}$ CSIS (Center for Strategic and International Studies). "Confidence-building measures”. 2018. < https:/www.csis.org/programs/international-securityprogram/isp-archives/asia-division/cross-strait-security-initiativ-1> Accessed on 8 April 2018; see also BS Glaser. "Cross-strait confidence building: The case for military-confidence building measures". 2005. $<$ https://www.csis.org/analysis/cross-strait-confidence-building-casemilitary-confidence-building-measures $>$ Accessed on 3 April 2018.

${ }^{259}$ Herbert op. cit., p. 3.

${ }^{260}$ OSCE op. cit., p. 10.

${ }^{261}$ Wolff $o p$. cit., p. 1.

${ }^{262}$ UN op. cit., p. 9.

${ }^{263}$ Barston op. cit., p. 200.

${ }^{264}$ Bearman op. cit., p. 40; Bisley op. cit., p. 13.

${ }^{265}$ Boutros-Ghali op. cit., par. 23.

${ }^{266}$ Lund op. cit., p. 203. 
${ }^{267}$ Ibid., p. 37.

${ }^{268}$ Wallensteen op. cit., p. 37; Mitchell op. cit., pp. 30-31.

${ }^{269}$ AZ Hilali. "Confidence- and security-building measures for India and Pakistan". Alternatives 30. 2005. 191-222; CSIS op. cit.

${ }^{270}$ OSCE. Vienna document 2011 on confidence- and security-building measures. Vienna, 2011.

${ }^{271}$ Lund op. cit., p. 203.

${ }^{272}$ A Ackermann. "The idea and practice of conflict prevention". Journal of Peace Research 40/3. 2003, 341.

${ }^{273}$ Cottey \& Forster op. cit., p. 279.

${ }^{274}$ Republic of Indonesia. Ministry of Defence. Defence White Paper 2015. Jakarta, 2015, 45-46.

${ }^{275}$ E Laksmana. "Defence diplomacy in Southeast Asia: Trends, prospects and challenges". In B Singh \& SS Tan (eds), RSIS monograph no. 21. Singapore:

S. Rajaratnam School of International Studies, 2011, 82.

${ }^{276}$ J Fris. Neither staunch friends nor confirmed foes: New Zealand's defence diplomacy in Asia. Wellington: Victoria University of Wellington, 2013.

${ }^{277}$ Ibid., p. 12.

${ }^{278}$ As quoted by G Swistek. "The nexus between public diplomacy and military diplomacy in foreign affairs and defence policy". Connections XI/2. Spring 2012. 79-86; and also by Winger op. cit.

${ }^{279}$ Fris op. cit., p. 18.

${ }^{280}$ Kingdom of Spain. Ministry of Defence. Defence diplomacy plan. Madrid, 2012, 18.

${ }^{281}$ Bearman op. cit.

${ }^{282}$ Rolfe op. cit., p. 1.

${ }^{283}$ Du Plessis op. cit., pp. $89 \& 92$.

${ }^{284}$ Cottey \& Forster op. cit., pp. 15-16. 